\title{
Kedudukan Hukum Ibukota Kabupaten Setelah Dimekarkan Menjadi Pemerintah Kota
}

\author{
Alinapia
}

DATA NASKAH

Masuk: 2 Januari 2017

Diterima: 22 Maret 2017

Terbit: 1 Juni 2017

KORESPONDEN PENULIS:

Fakultas Hukum Universitas Muhammadiyah Tapanuli Selatan Jl. St. Moh. Arif No. 32

Padangsidimpuan Sumatera Utara 22716

Email: alinapia131965@gmail.com

\begin{abstract}
The problems of this research are: firstly how is the law position of district capital city South Tapanuli after separated from Sidimpuan city? Secondly, what are the law effects of between double capital cities and two autonomy areas? In this research, it used law research method, with collected the data based on interview and documentation. It was analysis with hypotheses technique inductively and deductively, therefore it found that the position the main capital city of district South Tapanuli after separated from Padangsidimpuan is Padangsidimpuan. Although in constitutions of establishment Padang Lawas in 2007, it is determined Sipirok as the capital city, but it is realization in 2014. Meanwhile the effects of law double capitals, in generally can disturb the continuity of both government and especially it will happen discrepancy, minus work ethic, there is the classification of society, outdated of tradition "dalihan natolu" and easily to provoked both two government.
\end{abstract}

Keywords: Development, Capital City, and Double Capital

\section{ABSTRAK}

Permasalahan penelitian ini adalah, pertama, bagaimanakah kedudukan hukum Ibukota Kabupaten Induk ] setelah terjadinya pemekaran Kota Padangsidimpuan? Kedua, apa akibat hukum ibukota rangkap antara dua daerah otonom? Metode yang digunakan adalah metode penelitian hukum, dengan pengumpulan data berdasarkan interview dan studi dokumentasi. Setelah data di analisis dengan menggunakan teknik pengujian hipotesa berdasarkan metode induksi dan deduksi, maka diperoleh hasil bahwa kedudukan ibukota Kabupaten induk Tapanuli Selatan setelah terjadinya pemekaran Kota Padang- 
sidimpuan adalah tetap Padangsidimpuan, sekalipun dalam undang-undang Pembentukan Kabupaten Padang Lawas Utara dan Kabupaten Padang Lawas pada tahun 2007, menentukan Sipirok sebagai ibukotanya, tetapi baru terlaksana pada tahun 2014. Sedangkan akibat hukum ibukota rangkap yaitu secara umum dapat mengganggu kelancaran pelaksanaan pemerintahan diantara kedua pemerintahan, dan secara khusus berupa terjadinya kesenjangan, berkurangnya etos kerja, adanya pengklasifikasian masyarakat, lunturnya adat "dalihan natolu" dan mudahnya masyarakat terprovokasi antara dua pemerintahan.

Kata Kunci: Pemekaran, Ibukota, Ibukota Rangkap

\section{PENDAHULUAN}

Salah satu tuntutan reformasi 1998 adalah pemberian otonomi daerah kepada Pemerintah Kabupaten/ Kota. Pasal 18 ayat (1) UUD 1945 "Negara Kesatuan Republik Indonesia dibagi atas daerah daerah provinsi dan daerah provinsi dibagi atas kabupaten dan kota, yang tiap-tiap provinsi, kabupaten, dan kota itu mempunyai pemerintahan daerah, yang diatur dalam undang-undang". Ketentuan tersebut diperjelas dalam Pasal 18 ayat (2) yang menentukan bahwa: Pemerintahan daerah provinsi, daerah kabupaten, dan kota mengatur dan mengurus sendiri urusan pemerintahan menurut asas otonomi dan tugas pembantuan. Berdasarkan ketentuan Pasal 18 ayat (1) dan (2) tersebut dapat disimpulkan bahwa sistem yang diatur dalam UUD 1945 hasil amandemen tidak memberikan perbedaan antara Daerah Provinsi dengan Daerah Kabupaten/Kota, karena baik Daerah Provinsi mapun Daerah Kabupaten/ Kota sama-sama memiliki pemerintahan daerah serta kewenangan untuk mengatur dan mengurus urusan pemerintahan menurut asas otonomi dan tugas pembantuan (Muhammad Fauzan, 2015: 11).

Pemberian otonomi daerah dimaksudkan untuk mendekatkan pelayanan dan percepatan pembangunan serta pertumbuhan demokrasi dalam meningkatkan kesejahteraan masyarakat. Otonomi daerah diadakan bukan sekedar menjamin efisiensi penyelenggaraan pemerintahan. Bukan sekedar pula menampung kenyataan yang luas, penduduk banyak, dan berpulau-pulau. Lebih dari itu, otonomi daerah merupakan dasar memperluas pelaksanaan demokrasi dan instrumen mewujudkan kesejahteraan umum (Septi
Nurwijayanti, 2016:189). Sehingga konsekuensinya memberikan kesempatan seluas-luasnya kepada daerahdaerah untuk berkembang secara mandiri, pemberian kesempatan tersebut harus berkeadilan bagi daerah dan tidak mengurangi hak dan kewenangan daerah untuk mengaturnya (Tanto Lailam, 2017: 143). Menurut Murtir Jeddawi (2009:7-8), salah satu instrumen ke arah peningkatan pelayanan masyarakat adalah pengecilan rentang kendali (span of power) dalam daerah yang kemudian diterjemahkan menjadi pemekaran daerah. Asumsi dasarnya antara lain, wilayah-wilayah tertentu dalam daerah yang jaraknya jauh dari ibukota daerah, mendapat perlakuan yang sama, dengan demikian diperlukan pemekaran. Hal yang sama oleh Max H. Pohan (2008: i)., bahwa: "Pemekaran daerah secara intensif berkembang di Indonesia sebagai salah satu jalan untuk pemerataan pembangunan dan meningkatkan kesejahteraan masyarakat di daerah".

Keinginan masyarakat untuk ikut serta mewarnai dinamika sosial budaya dan pemerintahan di daerah, tidak lain adalah untuk kesejahteraan masyarakat melalui peningkatan pelayanan, dan pemberdayaan masyarakat. Demikian halnya Pemerintah Kota Padangsidimpuan yang lahir sebagai akibat pemekaran Kabupaten Tapanuli Selatan Tahun 2000, dengan Undang-undang No.4 Tahun 2001. Lahirnya Pemerintah Kota Padangsidimpuan, telah membawa masalah hukum yaitu terjadinya ibukota rangkap diantara kedua pemerintahan, antara kabupaten induk dengan daerah yang dimekarkan. Dikatakan demikian karena setiap pemekaran Pemerintah Kota tidak dicantumkan pasal tentang dimana kedudukan ibukota Kabupaten induk setelah terjadinya pemekaran. Akibatnya aktifitas pemerintahan akan terhambat karena tidak mungkin dua pemerintahan dengan satu ibukota.

Berdasarkan hal tersebut maka yang menjadi rumusan permasalahan dalam penelitian ini adalah:

1. Bagaimana kedudukan hukum ibukota kabupaten induk setelah terjadinya pemekaran Pemerintah Kota Padangsidimpuan?

2. Apa akibat hukum terjadinya ibukota rangkap antara dua daerah otonom?

\section{METODE PENELITIAN}

Penelitian ini merupakan penelitian hukum empiris (le- 


\section{MEDIA
HUKUM}

gal research). Data penelitian terdiri dari data primer dan data skunder, dengan populasi semua aparat Pemerintah Kabupaten Tapanuli Selatan dan Pemerintah Kota Padangsidimpuan. Sampel ditentukan berdasarkan teknik purposive sampilng dengan anggapan atau pendapatnya (judgment) sendiri mewakili populasi penelitian (Manasse Malo, Sri Tritoningtias, 1989: 103) yaitu, Ketua Badan Perencanaan Pembangunan (BAPPEDA), Ketua, Wakil Ketua Dewan Perwakilan Rakyat Daerah (DPRD) Tapanuli Selatan dan Kota Padangsidimpuan. Informan terdiri dari tokoh masyarakat, tokoh adat, dan cendikiawan. Pengumpulan data dengan wawancara mendalam (depth interview). Alat atau instrumen adalah daftar dan pedoman wawancara terstrukturyang disusun terlebih dahulu. Analisis data dengan menghubungkan hasil tinjauan pustaka, dengan masalah-masalah yang telah dirumuskan kemudian ditarik kesimpulan sebagai jawaban terhadap masalah tersebut. Analisis data dalam penelitian ini menggunakan deskriptif kualitatif, peneliti dalam menganalisis berkeinginan untuk memberikan gambaran atau pemaparan atas objek penelitian (Mukti Fajar dan Yulianto Achmad, 2010:183).

\section{HASIL PENELITIAN DAN ANALISIS}

Kedudukan Hukum Ibukota Kabupaten Induk Setelah Menjadi Pemerintah Kota Padangsidimpuan

\section{a. Periode 2001-2007}

Menurut Kamus Besar Bahasa Indonesia (2001: 416), ibukota adalah pusat pemerintahan suatu negara, atau daerah tempat unsur adminsitratif, yaitu eksekutif, legislatif dan yudikatif. Pamudji, menambahkan bahwa ibukota tidak hanya sebagai pusat pemerintahan, akan tetapi sebagai pusat pembangunan dan kemasyarakatan, masing-masing kegiatan saling berkaitan dan menunjang. Kegiatan pemerintahan merupakan kegiatan-kegiatan yang dilaksanakan oleh aparatur pemerintah dalam kerangka pemberian pelayanan dan usaha pembangunan. Kegiatan yang demikian itu perlu didukung oleh kegiatan kemasyarakatan sehingga menimbulkan kegiatan terintegrasi yang dengan sadar menimbulkan partisipasi masyarakat. Untuk itu baik Pemerintah Kota maupun ibu kota Kabupaten kedua-duanya merupakan pusat kegiatan pemerintah, pembangunan dan kemasyarakatan dalam Pemerintah Kota dan Kabupaten yang bersangkutan, sehingga dalam pengembangan ibukota terpisah antara Pemerintah Kota dan Kabupaten agar pertumbuhannya dapat diharapkan dari masing-masing Pemerintah Kota maupun Kabupaten (Pamudji S, 1985: 75).

Dari hal tersebut secara teoritis ibukota kabupaten dengan pemerintah kota harus terpisah agar pembangunan kedua daerah otonom dapat berjalan dengan baik. Akan tetapi hal tersebut tidak terjadi pada Undang-Undang No.4 Tahun 2001, bahkan dalam Pasal 16 undang-undang ini ditentukan bahwa semua peraturan perundang-undangan yang saat ini berlaku bagi Kabupaten Tapanuli Selatan tetap berlaku bagi Kota Padangsidempuan sebelum peraturan perundangundangan dimaksud diubah, diganti, atau dicabut berdasarkan undang-undang ini.

Disamping itu Undang-Undang No.4 Tahun 2001 juga memberi peluang kepada Kabupaten Induk Tapanuli Selatan mempertahankan Padangsidimpuan sebagai ibu kotanya. Hal ini sesuai dengan bunyi pasal 13 yaitu: "Untuk kelengkapan perangkat pemerintahan Kota Padangsidimpuan, dibentuk Sekretariat Dewan Perwakilan Rakyat Daerah Kota, Sekretariat Kota, Dinas Kota, dan Lembaga Teknis Kota sesuai dengan peraturan perundang-undangan".

Demikian juga halnya Pedoman Pelaksanaan Undangundang No. 4 Tahun 2001 sebagaimana diatur dalam Surat Menteri Dalam Negeri Republik Indonesia No. 135/2094/SJ tanggal 16 Oktober 2001 tentang Pedoman Pelaksanaan Undang-Undang Pembentukan Kota Padangsidimpuan, bahwa: "Seluruh fasilitas umum/sosial dan sarana/prasarana perkotaan seperti jalan, saluran pembuangan air hujan, saluran pembuangan air limbah, pasar, terminal, fasilitas pendidikan, kesehatan, peribadatan, rekreasi, kebudayaan, olahraga, taman kota, pemakaman umum, dan lain-lain yang berada di kota-kota yang baru terbentuk, kantor-kantor Pemerintah Daerah Kabupaten Induk yang selama ini digunakan sebagai eks Kota Administratif, sarana/pra sarana lainnya yang telah dihibahkan/diserahkan penggunaannya oleh Departemen/LNDP, pemerintah Provinsi dan Kabupaten Induk kepada Kota Administratif, agar secara formil dan material agar diserahkan kepada Pemerintah Kota Padangsidimpuan.

Hal tersebut menunjukkan bahwa Pemerintah Kota Padangsidimpuan yang baru lahir, diharapkan membentuk 
perangkat pemerintahannya (Pasal 13 Undang-undang No.4 Tahun 2001), sedangkan perangkat pemerintahan yang diserahkan pun adalah bekas atau yang telah dipakai oleh Pemerintah Kota Administratif pada masa statusnya sebagai Kota Administratif (Surat Mendagri Nomor 135/2094/SJ). Sehingga Pemerintah Kota Padangsidimpuan seolah-olah menumpang di daerah sendiri dalam melengkapi perangkat daerahnya. Hal mana seharunya Kabupaten induk yang mencari ibukotanya akibat peralihan Padangsidimpuan sebagai daerah otonom.

Disamping itu sesuai hasil wawancara penulis dengan tokoh masyarakat Kota Padangsidimpuan Jhonatan Siregar (2014), bahwa faktor adat sangat dominan bertahannya Kabupaten Induk Tapanuli Selatan di Kota Padangsidimpuan. Dalam hukum adat Tapanuli Selatan dan Kota Padangsidimpuan, sampai saat ini masih hidup ditengah-tengah masyarakat, yaitu adat "manjae" (pindah rumah). Adat "manjae" ini biasa dilakukan ketika anak laki-laki yang berumah tangga atau kawin. Adat Tapanuli Selatan dan Kota Padangsidimpuan sebagaimana masyarakat Batak umumnya menganut asas kekeluargaan "patrilinial" (berdasarkan keturunan ayah) (J.C. Vergouwen, 2004: 1).

Menurut asas patrilinial bahwa anak laki-laki yang kawin dengan seorang wanita, akan membawa isterinya kerumah orang tuanya. Sehingga dalam keluarga patrilinial klan yang hidup adalah klan suami, sedangkan istri masuk ke dalam klan suaminya. Misalnya ayah marga Harahap dan istri Siregar (suatu marga di Tapanuli Selatan dan Padangsidimpuan) (G. Siregar Baumi Gelar Ch. Sutan Tinggibarani Perkasa Alam, 1984: 19), maka anak bermarga Harahap. Hal mana berbeda dengan "matrilinial" (berdasarkan klan ibu). Marga adalah merupakan suatu kesatuan kelompok yang mempunyai garis keturunan yang sama berdasarkan nenek moyang yang sama (Bungaran Antonius Simanjuntak, 2006: 76).

Adat manjae berawal dari perkawinan anak, dan biasanya masih tinggal di rumah orang tua anak laki-laki. Anak yang berkeluarga tidak mungkin selamanya tinggal bersama orang tuanya, untuk itu harus dipindahkan, inilah yang disebut dengan adat manjae. Prosesi manjae ini pada awalnya pihak orang tua anak laki-laki dan kerabatnya akan mencarikan kayu dan bahan perlengkapan lainnya ke hutan untuk membuat rumah sederhana tempat tinggal anak yang sudah berkeluarga tersebut, dan biasanya, rumah dibangun tidak jauh dari rumah orangtua anak laki-laki. Mencari kaya kehutan biasanya disebut "Martoktok Hayu Tu Harangan" (mengambil kayu ke hutan) (G. Siregar Baumi Gelar Ch. Sutan Tinggibarani Perkasa Alam, 1984: 94). Kemudian setelah rumah selesai dibangun, di adakan upacara manjae dengan memberikan perlengkapan dan belanja kebutuhan hidup anak dan keluarganya selama satu bulan, ditambah semua barang-barang yang di peroleh pada waktu prosesi pernikahan di pihak istri. Akan tetapi, saat ini proses adat manjae telah bergeser dari mencari perlengkapan pembuatan rumah dari hutan, dengan mengontrak rumah di tempat lain, sekalipun tidak jauh dari rumah orang tua anak lakilaki.

Berdasarkan hal tersebut falsafah adat manjae ini menunjukkan bahwa hubungan kekerabatan antara anak dengan orang tua tidak pernah putus, sekalipun anak sudah berkeluarga. Hal ini terbukti bahwa orang tua masih mengusahakan pemindahan anaknya yang sudah berkeluarga ke tempat lain dengan memberikan biaya hidup anak, sebelum bisa mandiri membiayai keluarganya. Dari hal tersebut Pemerintah Kabupaten Tapanuli Selatan tetap bertahan di Kota Padangsidimpuan, karena secara adat bahwa Kota Padangsidimpuan lahir dari pemekaran Kabupaten Tapanuli Selatan, maka Padangsidimpuan sebagai anak harus menghormati orangtuanya Kabupaten Tapanuli Selatan, karena menurut hukum adat yang harus pindah adalah Kota Padangsidimpuan, tetapi menurut Undang-undang No.4 Tahun 2001 yang pindah justru orang tuanya yaitu Kabupaten Tapanuli Selatan.

Dengan kondisi tersebut kedua pemerintahan saling mempertahankan Padangsidimpuan sebagai ibu kotanya masing-masing, karena menurut Undang-undang Darurat No.7 Tahun 1956 tentang Pembentukan Pemerintah Kabupaten Tapanuli Selatan dengan ibukota Padangsidimpuan (Pasal 2 ayat 1 butir 10 Undang-undang Darurat No.07 Tahun 1956), demikian juga halnya Undang-undang No.4 Tahun 2001 (Pasal 3 Undang-Undang Nomor 4 Tahun 2001). Yang menjadi pertanyaan adalah apa dasar pemikiran pembuat Undang-undang No.4 Tahun 2001 tidak mencantumkan ibu kota kabupaten induk Tapanuli Selatan setelah lahirnya Pemerintah Kota Padangsidimpuan?. Apabila dirujuk pada 


\section{MEDIA
HUKUM}

dasar pembentukan Undang-undang No.4 Tahun 2001 yaitu Undang-undang No.22 Tahun 1999 tentang Pemerintahan Daerah, dapat diketahui bahwa ada pasal yang mengatur tentang pemindahan ibu kota setelah terjadinya pemekaran (Pasal 5 ayat (3). Sehingga kalau tidak diatur tentang ibukota kabupaten induk dalam Undang-undang No.4 Tahun 2001 tersebut, kelak suatu saat secara bertahap akan dipindahkan dengan proses yang lebih mudah yaitu dengan peraturan pemerintah. Akan tetapi belum sampai keluarnya Peraturan Pemerintah tentang pemindahan ibukota Kabupaten Tapanuli Selatan, telah keluar Undang-undang No.37 Tahun 2007 Jo Undang-undang No.38 Tahun 2007 tentang Pembentukan Kabupaten Padang Lawas Utara dan Kabupaten Padang Lawas, hal mana dalam undang-undang ini ditentukan bahwa Sipirok adalah ibukota Kabupaten Tapanuli Selatan.

Dengan demikian jelaslah bahwa Padangsidimpuan tetap menjadi ibu kota kabupaten induk Tapanuli Selatan, sekaligus Pemerintah Kota Padangsidimpuan sebelum lahirnya Undang-undang No.37 Tahun 2007 Jo Undang-undang No.38 Tahun 2007, yaitu dari tahun 2001 sampai tahun 2007.

\section{b. Periode 2007-2014}

Persoalan ibu kota kabupaten induk Tapanuli Selatan tidak selesai dalam tataran saling mempertahankan Padangsidimpuan sebagai ibu kota bersama dengan Pemerintah Kota Padangsidimpuan. Hal ini berlanjut dengan lahirnya daerah pemekaran baru yang juga merupakan pemekaran Kabupaten Tapanuli Selatan, yaitu Pemerintah Kabupaten Padang Lawas Utara dan Kabupaten Padang Lawas dengan Undang-undang No.37 Tahun 2007 dan Undang-undang No.38 Tahun 2007.

Dengan lahirnya undang-undang ini maka ibukota Kabupaten Tapanuli Selatan yang merupakan kabupaten induk sejak tahun 2007 berkedudukan di Sipirok (Pasal 21 ayat (1) Undang-undang No.37 Tahun 2007 Jo Pasal 21 ayat (1) Undang-undang No.38 Tahun 2007. Dengan proses pemindahan paling lama 18 bulan sejak diundangkan, secara definitif, pusat kegiatan penyelenggaraan pemerintahan Kabupaten Tapanuli Selatan telah berada di Sipirok (Pasal 21 ayat (2) Undang-Undang No. 37 Tahun 2007 Jo Pasal 21 ayat (2) Undang-undang No.38 Tahun 2007). Dengan demikian sejak 10 Maret 2009 ibukota Kabupaten
Tapanuli Selatan sudah harus berada di Sipirok, akan tetapi sekalipun secara yuridis sudah ada aturan untuk itu, ternyata baru terealisasi pada tahun 2014. Sehingga walaupun dalam Undang-undang No.37 Tahun 2007 bahwa Kabupaten Tapanuli Selatan ibukotanya Sipirok, ternyata jalan terjal menuju Sipirok harus berliku melalui jalan pintas dengan kucing-kucingan berkantor di Kota Padangsidimpuan.

Akhirnya Padangsidimpuan tetap menjadi ibukota Kabupaten Tapanuli Selatan sejak tahun 2001-2007, kemudian kalau pun Sipirok telah ditentukan menjadi ibukota Kabupaten Tapanuli Selatan dalam undang-undang, ternyata hal tersebut baru terealisasi pada tahun 2014. Maka selama 14 tahun Padangsidimpuan menjadi ibukota rangkap antara Kabupaten Tapanuli Selatan dengan Kota Padangsidimpuan.

\section{Akibat Hukum Terjadinya Ibukota Rangkap}

Secara teoritis terjadinya ibu kota rangkap merupakan akibat dari perubahan sosial, yaitu berubahnya keadaan Kabupaten Tapanuli Selatan menjadi Pemerintah Kota Padangsidimpuan dengan Undang-undang No.4 Tahun 2001. Lahirnya undang-undang ini terjadilah perubahan sosial terhadap masyarakat di Kota Padangsidimpuan. Menurut Roscoe Pound sebagai peletak dasar teori ini mengatakan bahwa hukum sebagai alat perubahan sosial (Law as a Tool of Social Engineering) (Roscoe Pound, 1978: 3). Sedangkan Satjipto Rahardjo, berpendapat bahwa hukum sebagai social engineering dalam masyarakat modern dilakukan secara sadar untuk mencapai tujuan-tujuan tertentu (Satjipto Rahardjo, 1983: 86).

Kemudian menurut Pound, pertanyaan yang muncul, apa yang harus digarap oleh hukum dalam konteks social engineering? Jawabannya adalah menata kepentingankepentingan yang ada dalam masyarakat, kepentingankepentingan tersebut harus ditata sedemikian rupa agar tercapai keseimbangan yang proporsional. Manfaatnya adalah terbangunnya suatu struktur masyarakat sedemikian rupa hingga secara maksimum mencapai kepuasan akan kebutuhan dengan seminimum mungkin menghindari benturan-benturan dan pemborosan. Lalu apa sajakah kepentingan-kepentingan dimaksud? Pound mengajukan tiga kategori kelompok kepentingan, yaitu kepentingan umum, 
sosial dan kepentingan pribadi (Bernard L. Tanya dkk., 2010: 155).

Di Indonesia teori Pound ini direkayasa oleh Mochtar Kusumaatmajda dengan "Teori Hukum Pembangunan", yang inti teorinya bahwa pengertian hukum sebagai alat menjadi hukum sebagai sarana untuk membangun masyarakat. Pokok-pokok pikiran yang mendasari konsep tersebut adalah bahwa keterlibatan dan keteraturan dalam usaha pembangunan dan pembaharuan memang diinginkan, bahkan mutlak perlu agar dapat mengarahkan kegiatan manusia ke arah yang dikehendaki oleh pembangunan dan pembaharuan. Oleh karena itu, maka diperlukan sarana berupa peraturan hukum yang tertulis dan sesuai dengan hukum yang hidup dalam masyarakat (Wicipto Setiadi, 2012: 6-7).

Dengan demikian sesuai teori Roscoe Pound tersebut, jelaslah bahwa akibat pemekaran dengan ibu kota rangkap antara Kabupaten Tapanuli Selatan dan Kota Padangsidimpuan, akan menimbulkan konflik sosial dan hukum, untuk itu harus ditata sesuai dengan hukum yang berlaku, misalnya ibukota harus dipindahkan, berikut dengan aset dan sumber daya manusia yang ada demi kepentingan bersama, serta menghindari seminim mungkin benturan-benturan antara dua komponen pemerintahan yaitu Kabupaten Tapanuli Selatan dan Kota padangsidimpuan. Demikian Mochtar Kusumaatmadja (2002: 20), dengan teori hukum pembangunannya yang merupakan rekayasa dari teori Law as a Tool of Social Engineering, bahwa hukum itu sebagai alat perubahan pembangunan, sehingga peraturan hukum yang lahir sebagai akibat pembangunan dan perubahan sosial, maka ibukota rangkap tidak seharusnya terjadi karena setiap peraturan itu sebagai akibat dari proses pembangunan.

Hal ini sesuai dengan pendapat Ilhami, bahwa dalam rangka peningkatan efisiensi pemerintah agar diadakan pemindahan ibukota kabupaten yang berada pada pemerintah kota karena kalau tidak terpisah antara ibukota kabupaten dengan pemerintah kota akan mengalami perkembangan yang kurang sehat, oleh karena itu pemerintah kabupaten yang tidak memiliki yurisdiksi kewenangan wilayah pemerintahan pemerintah kota akan memusatkan pembangunan pelayanan masyarakat dan sebagainya di daerah perbatasan pemerintah kota dan kabupaten (Ilhami, 1990: 66).
Dengan pendapat tersebut seharusnya antara ibukota Kabupaten Induk Tapanuli Selatan dan Kota Padangsidimpuan harus terpisah, karena secara administrasi kedua daerah tersebut merupakan daerah otonom yang, dan harus melaksanakan pemerintahannya dengan ibu kota masingmasing. Sebagaimana telah diuraikan diatas bahwa pemekaran Kota Padangsidimpuan telah membawa pengaruh terhadap pelaksanaan pemerintahan antara kedua pemerintah daerah otonom. Adapun pengaruhnya berdasarkan hasil penelitian adalah sebagai berikut:

a. Adanya kesenjangan antara Kabupaten Induk dengan Pemerintah Kota Padangsidimpuan karena terdapatnya dua daerah otonom dalam suatu ibu kota pemerintahan yaitu Padangsidimpuan.

b. Berkurangnya etos kerja masing-masing aparat pemerintahan, karena terusik akibat saling mempertahankan kepentingan antara Pemerintah Kota Padangsidimpuan dengan Kabupaten Induk. Kabupaten induk yang melahirkan Pemerintah Kota Padangsidimpuan, beranggapan bahwa keberadaan mereka di Padangsidimpuan tetap sebagai penentu kebijakan diantara kedua pemerintahan, bagaikan kakak dengan adek. Akan tetapi Pemerintah Kota Padangsidimpuan berasumsi lain bahwa dengan lahirnya Undang-undang Nomor 4 Tahun 2001 tidak ada lagi hak kabupaten induk di Padangsidimpuan, dan harus pindah ke tempat lain di wilayah hukum Kabupaten Tapanuli Selatan.

c. Berkurangnya Dana Alokasi Umum (DAU) dan Dana Alokasi Khusus (DAK) bagi Kabupaten induk. Karena dalam Undang-undang No.4 Tahun 2001 ditentukan bahwa semua biaya yang timbul akibat pemekaran harus diambil dari APBD kabupaten induk.

d. Terjadinya pengklasifikasian masyarakat antara Kota Padangsidimpuan dengan kabupaten Induk, terutama yang bekerja di kabupaten induk dengan yang bekerja di Kota Padangsidimpuan.

e. Lunturnya tatanan kekerabatan yang selalu dihormati oleh masyarakat Tapanuli Selatan dan Kota Padangsidimpuan yaitu "Dalihan Natolu" (tiga tungku) yang merupakan struktur masyarakat Tapanuli Selatan dan Kota Padangsidimpuan, bagaikan tiga kekuatan yang saling menopang antara Mora (kerabat orang tua isteri), Anak 
Boru (kerabat suami istri) dan Kahanggi (kerabat saudara dari suami). Kalau falsafah ini dihormati dimana pun masyarakatnya akan selalu tenang dan tenteram, karena diikat dengan hubungan darah dan perkawinan yang mempertalikan dalam satu kelompok (L.S., Diapari Gelar Patuan Naga Humala Parlindungan, 1987: 57).

f. Mudahnya masyarakat terprovasi isu-isu negatif dalam pelaksanaan Undang-undang No.4 Tahun 2001, terutama di wilayah tapal batas diantara kedua belah pihak, yang sering memicu kerusuhan antara Kabupaten Induk dengan Pemerintah Kota Padangsidimpuan. Seperti halnya dengan pembentukan Kecamatan baru dilingkungan Pemerintah Kota Padangsidimpuan pada tanggal 13 Nopember 2001, terjadi demonstrasi masyarakat yang pro dan kontra antara yang mendukung pemerintah Kota Padangsidimpuan dan Kabupaten Tapanuli Selatan (Alinapia, 2003: 70).

\section{SIMPULAN}

Berdasarkan uraian tersebut dapat disimpulan sebagai berikut:

1. Bahwa kedudukan ibu kota Kabupaten Tapanuli Selatan setelah terjadinya pemekaran menjadi Pemerintah Kota adalah adalah tetap menjadi ibu kota kedua Pemerintahan antara Kabupaten Tapanuli Selatan dan Pemerintah Kota Padangsidimpuan dari tahun 2001 sampai tahun 2014. Sekalipun setelah lahirnya Undang-undang No.37 Tahun 2007 dan Undang-undang No.38 Tahun 2007 tentang pembentukan Pemerintah Kabupaten Padanglawas Utara dan Padang Lawas, ada ketentuan bahwa Sipirok menjadi ibukota Tapanuli Selatan, akan tetapi baru bisa dipindahkan pada tahun 2014.

2. Pengaruh ibu kota rangkap antara Kabupaen Induk dan Pemerintah Kota Padangsidimpuan pada umumnya dapat mengganggu kelancaran pelaksanaan roda pemerintahan diantara kedua pemerintahan, akan tetapi secara khusus adalah sebagai berikut:

a. Ada kesenjangan antara dua pemerintahan.

b. Berkurangnya etos kerja antara kedua pemerintahan.

c. Terjadinya pengklasifikasian masyarakat antara dua pemerintahan.

d. Lunturnya tatanan kekerabatan masyarakat Dalihan
Natolu diantara dua pemerintahan

e. Mudahnya masyarakat terprofokasi diperbatasan antara dua pemerintahan.

\section{DAFTAR PUSTAKA}

\section{Buku dan Artikel}

Depdiknas, 2001, Kamus Besar Bahasa Indonesia, Balai Pustaka, Jakarta.

Fajar, Mukti, dan Yulianto Achmad, Dualisme Penelitian Hukum Normatif dan Empiris, Yogyakarta, Pustaka Pelajar

Muhammad Fauzan, "Peluang Titik Berat Otonomi Pada Daerah Provinsi dalam Sistem Ketatanegaraan Republik Indonesia”, Jurnal Media Hukum Volume 23. No.1 Juni 2016

G. Siregar Baumi Gelar Ch. Sutan Tinggibarani Perkasa Alam, 1984, Surat Tumbaga Holing Adat Batak Angkola-Sipirok-Padangbolak-Barumun- Mandailing Nata-Natal, Tanpa Penerbit, Padangsidimpuan.

Ilhami, 1990, Strategi Pembangunan Perkotaan di Indonesia, Surabaya, Usaha Nasional

Jeddawi, Murtir, 2009, Pro Kontra Pemekaran Daerah (Analisis Empiris), Yogyakarta, Total Media

J.C. Vergouwen, 2004, Mayarakat dan Hukum Adat Batak Toba, Yogyakarta, LKIS.

Lailam, Tanto, 2017, Teori dan Hukum Perundangundangan, Yogyakarta, Pustaka Pelajar

L.S., Diapari Gelar Patuan Naga Humala Parlindungan, 1987, Perkembangan Adat Istiadat Masyarakat Suku Batak Tapanuli Selatan Suatu Tinjauan, Jakarta, Tanpa Penerbit

Malo, Manasse., Sri Tristoningtias, 1989, Metode Penelitian Masyarakat, Pusata Antar Universitas IlmuIlmu Sosial, Jakarta, Universitas Indonesia

Nurwijayanti, Septi, "Hubungan Antara Pusat dan Daerah Dalam Negara Kesatuan Republik Indonesia Berdasarkan Undang-Undang Nomor 23 Tahun 2014", Jurnal Media Hukum Volume 23 No.2 Desember 2016

Pohan, Max H., 2008, Studi Evaluasi Dampak Pemekaran Daerah 2001-2007,Jakarta, Bridge

Pamudji S., 1985, Pembinaan Perkotaan di Indonesia, Tinjauan dari AspekAdministrasi Pe merintahan, Jakarta, Rineka Cipta 
Pound, Roscoe, 1978, Filsafat Hukum, Jakarta, Bhratara Rahardjo, Satjipto 1983, Hukum dan Perubahan Sosial Suatu Tinjauan Teoritis Serta Pengalaman-Pengalaman di Indonesia, Bandung, Alumni

Simanjuntak, Bungaran Antonius, 2006, Struktur Sosial dan Sistem Politik Batak Toba Hingga 1945 Suatu Pendekatan Sejarah, Antropologi Budaya Politik, Jakarta, Yayasan Obor Indonesia

Tanya, Bernard L. dkk., 2010, Teori Hukum: Strategi Tertib Manusia Lintas Ruang dan Generasi, Yogyakarta, Penerbit Genta Publishing

Wicipto Setiai, "Penegakan Hukum dalam Rangka Peningkatan Supremasi Hukum (Development of Law in Order Enhanchement Supremacy of Law, dalam Jurnal Rechtsvinding, Volmue 1 Nomor 1, Januari-April 2012.

\section{Tesis/ Disertasi}

Alinapia, 2003, Pemekaran Kabupaten Tapanuli Selatan dan Masalahnya Ditinjau dari Pelaksanaan UU No. 4 Tahun 2001, dalam "Tesis” Tidak Dipublikasikan, Program Pascasarjana Universitas Andalas Padang.

\section{Peraturan Perundang-Undangan}

Undang-Undang Nomor 22 Tahun 1999 tentang Pemerintahan Daerah.

Undang-Undang Nomor 4 Tahun 2001 tentang Pembentukan Kota Padangsidimpuan.

Undang-Undang Nomor 37 Tahun 2007 tentang Pembentukan Kabupaten Padang Lawas Utara.

Undang-Undang Nomor 38 Tahun 2007 tentang Pembentukan Kabupaten Padang Lawas.

Surat Menteri Dalam Negeri Nomor 135/2094/SJ tanggal 16 Oktober 2001 tentang Pedoman Pelaksanaan Undang-Undang Pembentukan Kota Padangsidimpuan 